\title{
Teaching Material Development of Bahasa Indonesia Course As a Way to Develop the Lectures' Professional Development
}

\section{Anisa Ulfah and Jumaiyah}

Islamic University of Darul 'Ulum, Lamongan

\section{Abstract}

Teaching material is one of the instructional components that can optimize the learning outcome, competence and objectives, including bahasa Indonesia course in a university. Bahasa Indonesia is of personality development courses in university which emphases on students' ability to practice bahasa Indonesia, particularly in academic writing ability as a media to scientifically communicate in an appropriate, honest and responsible manner. Students can achieve the ability if they get learning experience in accordance with the course objective. To be able to provide a learning experience, a lecturer is required to have teaching materials developed in accordance with the

Corresponding Author:

Anisa Ulfah

anisaulfah.pbi@gmail.com

Received: 23 January 2019 Accepted: 26 February 2019 Published: 17 March 2019

Publishing services provided by Knowledge E

(c) Anisa Ulfah and

Jumaiyah. This article is

distributed under the terms of the Creative Commons

Attribution License, which permits unrestricted use and redistribution provided that the original author and source are credited.

Selection and Peer-review under the responsibility of the International Seminar on Language, Education, and Culture Conference Committee.

\section{G OPEN ACCESS} students' needs and proposed final competence. It is necessary for lectures to include various skills to be able to develop teaching materials in accordance with the students' need, including the capability of; designing, performing, and evaluating the instructional materials. Developing a good teaching material means developing lectures' capability to be professional. Therefore, developing teaching materials is a way of training and developing lectures' professionals.

Keywords: teaching materials' development, bahasa Indonesia course, professional lecturer

\section{1. introduction}

Bahasa Indonesia course is of personality development courses (mata kuliah pengembangan kepribadian/ MPK) in accordance with the decision letter of directorate general of higher education No: 43 (Dikti, 2006). The basic competence of the course is developing students to be a scholar, a scientist, and a professional who possess intellectual and positive emotional toward bahasa Indonesia as a national language. Also, students are expected to apply bahasa Indonesia in an appropriate manner to deliver the understanding, express nationality and patriotism, as well as others scientific necessities.

To achieve the course objective in an optimal way, the lecturing should be performed along with the assistance of a teaching material. The teaching material required for a 
lecturer of bahasa Indonesia is developed along with the course objectives. Therefore, to develop the teaching material of bahasa Indonesia course, a lecture is required to consider the following concerns; (1) relate to the expected learning objective, (2) support the students' motivation, (3) assist the students' active involvement, (4) adjust to the followed learning procedures (Winkel, 1991:45). On the other hand, the developed teaching materials should facilitate the students to master the materials so that they are able to achieve the success indicators in an optimum way. Hence, the materials should be arranged in accordance with the syllabus designed as the curriculum (Nyoto, 1996:53).

One of the previous studies on teaching materials development of bahasa Indonesia course had been completed at the State University of Malang (Widyartono, 2010) which produced an interactive web-based teaching material accessible only for internet-based users. Unlike the previous study, the current study produced a printed teaching material so that lectures and students were able to easily use it without internet connection. Also, it should be adjusted to the University students' needs and characteristics in Lamongan.

Teaching material development is a way to develop lectures' professionalism because the professionalism reflects their pedagogical competence. The pedagogical competence is a lectures' capability to design and apply the instructional in a right and appropriate way so that the lecturing process occurs effectively and efficiently (Redjeki, 2015:8). As stated that the existence of teaching materials in accordance with and appropriate to the curriculum and students' need, the lecturing process must occur optimally. For that reason, a lecture is expected to have the capability to develop the teaching materials as a way to improve a lecture professional.

\section{Method}

\subsection{Research design}

This study applied the design of research and development (R\&D) model adapted and modified from Borg and Gall (2007: 75) which arranged for ten research phases, including (1) research and information collecting, (2) planning, (3) developing preliminary form of product, (4) preliminary field testing, (5) operational field testing, (6) operational product revision, (7) main field testing, (8) main product revision, (9) final product revision, and (10) dissemination and implementation. The stages were adapted and adjusted to the objectives and students' needs. For that reason, the development stages applied to the current research were (1) pre-development, (2) development, (3) field testing and, (4) 
revision. In accordance with the aforementioned stages, it is obtained four main stages described as in Figure 1.

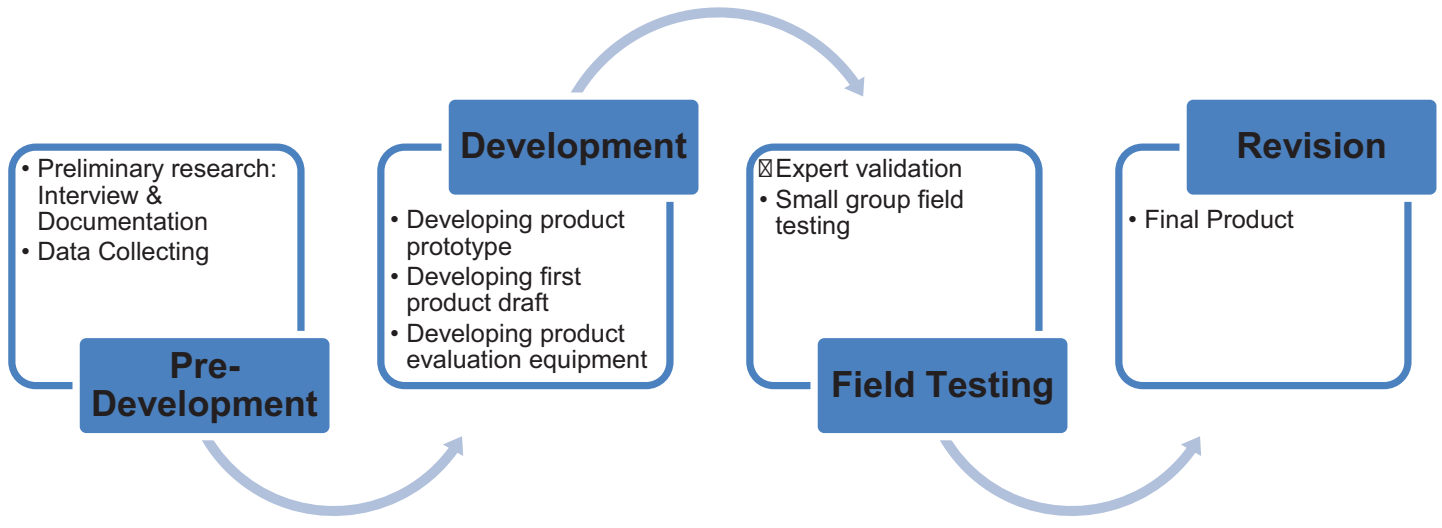

Figure 1: The Stages of the Research and Development.

\subsection{Data and source of the data}

The source of the data employed in the study was the lectures of bahasa Indonesia course at University in Lamongan by which other data about instructional design like semester learning plan (rencana pembelajaran semester/ RPS) and teaching material used as well as assignments given to the students were obtained. The lectures were also the subject of the study in the stage of product field testing as well as the students who took bahasa Indonesia course at the stage of product field testing to obtain the data about the product practicability.

\subsection{Data collection and instrument}

The research data were collected through interview, documentation, and questionnaire. Interview was used to collect the information on the pre-development product stage and applied to the lectures, while documentation study was utilized to obtain the data and information by exploring and learning the instructional design gained from the lectures. Questionnaire was applied to get the information about the practicability of the product done at the stage of field testing product.

\subsection{Data analysis technique}

The data obtained were analyzed through both qualitative and quantitative manner. The technique of qualitative data analysis was a descriptive qualitative to analyze the data 
gained from the result of interview, documentation, and questionnaire in the form of critics and suggestions notes. Meanwhile, the quantitative data were analyzed through validation result at the stage of field testing by converting the data into a percentage form. The data analysis was done early and during the process of research in a circular and interactive approach, round and simultaneous, based on the research requirement. The step of data analysis was employed through data collecting, reducing, presenting and verifying (Miles \& Huberman, 1984:56). Data collection was done continuously and simultaneously during the process of collection until it described and achieved the research objectives, teaching material profile of bahasa Indonesia course. Data reduction was used to get the data based on the need of prototype and product development. Data presentation was a process of organizing the data and information in a systematic way based on the research's need. Data verification employed during the data collection by analyzing, interpreting, and explaining the reduced data.

\section{Findings and Discussion}

The current research and development produced a teaching material product of bahasa Indonesia course, including (a) the description of learning outcomes of the course (capaian pembelajaran mata kuliah/CPMK), (b) semester learning plan (rencana pembelajaran semester/RPS), (c) lesson plan (rencana pelaksanaan pembelajaran/RPP), and (d) the course contract. The first, the description of CPMK is the learning outcomes statement whereby students are required to achieve after learning bahasa Indonesia in a semester. The CPMK is "After completing bahasa Indonesia course, students are able to apply the insight of bahasa Indonesia as a nationalism form of bahasa Indonesia and make the use of their bahasa Indonesia capability as a medium to communicate scientifically in an appropriate, honest, and responsible manner. The second, RPS is a map of a course topics arranged and designed to present it in a semester. The intended topics are (a) the position, function and variety of bahasa Indonesia, (b) the spelling system of bahasa Indonesia (ejaan bahasa Indonesia/EBI), (c) the sentence and paragraph writing, (d) the scientific article writing, consist of writing research proposal, the research result report, and scientific article. The teaching method applied to the classroom as well as the assessment techniques for each intended final competence were attached within RPS. The third, RPP is a description of some steps of activities' in the learning process based on the teaching method stated in the RPS. The fourth, the course contract is an agreement between the lecture and the students about the topics and materials for 
semester learning in accordance with the RPS along with the assignments the students must complete as a requirement the RPS implementation.

The teaching material is of instructional devices consist of competence and materials arranged in a systematic and coherent way to achieve the learning outcomes. The competence within the teaching materials involve cognitive, psychomotor, and affective (Nurgiantoro, 2008) which are stated in the CPMK, RPS, RPP and the course contract. Sungkono (2003) argued that the materials might involve ideas, facts, concepts, principles, or theories about the topics developed according to the intended final competence. To be able to develop the materials based on materials' development principles, a lecture must possess an adequate pedagogical competence. A professional lecture should have the capability to design, perform and evaluate the learning outcomes (UU Nomor 14, 2005). Consequently, a lecture capability to develop the teaching materials was a way to improve lectures' professional because they are required to prepared the materials, develop the teaching methods, as well as determine the appropriate evaluation technique based on the intended final competence.

The aspects assessed in the content of the teaching materials contained; the identity, the systematization of presentation and the accurateness of learning activities. These three aspects were required to assess due to the lectures' need to care for every details and not to be careless in developing the teaching materials. To develop the teaching materials, the lectures need to seek the students' attention to the intended final competence, the taught materials, and its methods to achieve the competence (Sadiman, 2008:182). The teaching materials identity is a component to appear in the teaching materials because the material development was required to care for the users and their intended competence. The systematization and accurateness of learning activities were the description of the teaching method so that the learning activities were presented in the teaching materials appropriately in order to achieve the final competence optimally. It is in accordance with the statement of Arifin \& Setiyawan (2012:56) who explained that the learning strategy is an action plan or the activity sequences to achieve the objective and the final competence, including the use of the method and various resources in the teaching and learning process.

The lectures' accurateness to decide the method to present the teaching materials was a realization of their depth and extent mastery of the teaching materials. A lecture who mastered the teaching materials properly would be able to determine the appropriate strategy to present them along with the activities. Sadjati (2012:29) stated that the learning strategies were the lectures' key to arrange the learning sequences and design the students' learning activities. The learning sequences were closely related 
to the topics and teaching materials that a lecture must be able to present them in a proper sequence and systematic way. A disorganized learning sequence would cause misunderstanding and confusion among the students. To be able to present the systematic learning, lectures must master all the theories and concepts of the teaching materials so that they are able to sort and select which materials should come first in appropriate sequences of the topics. A lecture is required to make competence map initially to make them easy mapping and sequencing the teaching materials presentation (Sadjati, 2012:27). By the sequence activities completed by the lectures to develop the teaching materials, their professionalism entailed to their activities in developing the teaching materials.

A good teaching material was delivered in an effective language indicated by the sentence intelligibility, either in delivering the concept or giving the instruction of the students' learning activities. If some complicated sentences used within the teaching materials which were difficult to understand and comprehend, the given information and instruction could not be delivered in an appropriate manner. Ulfah (2017:15) asserted that all the command, instruction and information must be delivered in an intelligible language, not the complicated one. It is necessary to consider those elements because the communication was of significant element lead to understanding and comprehension and to avoid misinterpretations and students questioning some complicated sentences. The one who develop the teaching materials must be able to produce a proper communicative language delivered within it. They also need to consider applying an interactive language, not to make it static. For that reason, the teaching materials should not only employ a formal language, but it could be mixed by some verbal language in an oral communication to create an interactive communication language (Mbulu \& Suhartono, 2004:105).

Furthermore, the presentation of the teaching materials developed must be able to catch the students' attention from its attractiveness, color harmony, and layout proportionality. An interesting teaching material would give the readers motivation to keep an eye on the learning activities presented. For that reason, the layout, color elements, and picture or table illustration must be presented in a harmony and interrelated one another (Muslich, 2010:306). Additionally, Ulfah (2017:14) explained that color combination applied to the teaching materials must be appropriate, not to distract the readers, moreover if there were topics explanation to read. In other words, if there were picture and table illustration in the teaching material, the color selection and its layout should be 
proportional to attain students' learning motivation from the teaching materials developed. Abovementioned elements of presentation skills must be mastered and developed though training it in a simultaneous and continuous way to develop the teaching materials. Therefore, both pedagogical and professional competence of a lecture could be developed simultaneously to present an innovative and effective learning.

\section{Conclusions and Suggestions}

\subsection{Conclusions}

The product produced in this research and development was the teaching materials of bahasa Indonesia, including CPMK, RPS, RPP, and the course contract. The teaching material was assessed based on its content, language, and presentation. The material development involved lectures' capability to produce an attractive and practical teaching material. The capability included designing, performing, and evaluating the learning process and outcome. The designing capability was done by mapping the materials to present based on the learning principle and determining the teaching methods and assessment technique to evaluate the learning outcome. Aforementioned capabilities were required to master for a professional lecturer. Therefore, the material development was a way to training and developing lectures' professional.

\subsection{Suggestions}

Since the current development research produced a teaching material product according to the students' and lectures' need at the university in Lamongan, the users of the product are expected to give extra the materials needed based on the need. For the future study, it is expected to do a similar research about the effectiveness of the current the teaching materials product in the teaching and learning process.

\section{References}

[1] Dokumen Negara tentang Rambu-Rambu Pelaksanaan Kelompok Mata Kuliah Pengembangan Kepribadian di Perguruan Tinggi, (Online), Retrieved May 13, 2017 from http://kelembagaan.ristekdikti.go.id/wp-content/11/skdirjen43-DIKTI-Kep2006.pdf

[2] Winkel, W.S. (1991). Psikologi Pengajaran. Jakarta: Grasindo. 
[3] Nyoto, A. (1996). Reorganisasi Buku Teks Mata Pelajaran Mekanik Otomotif Dasar dalam Jurnal Teknologi Pembelajaran Vol. 4, No. 1, 1996.

[4] Widyartono, D. (2010). Pengembangan Bahan Ajar Mata Kuliah Bahasa Indonesia Berbasis Web Interaktif. Malang: UM Graduates study. Unpublished Thesis.

[5] Redjeki, S. (2015). Pengembangan Profesionalisme Dosen dan Inovasi Pembelajaran. Dalam Majalah IImiah Pawiyatan. Vol: XXII, No.3, October 2015, (Online), Retrieved May 23, 2018 from http://e-journal.ikip-veteran.ac.id/index.php/pawiyatan/article/ view/424

[6] Borg, W.R. \& Gall, M.D. (2007). Educational Research: an Introduction. University of Michigan: Pearson Education.

[7] Miles, M.B. \& Huberman A.B. (1984). Qualitative Data Analysis: A Sourcebook of New Methods. California: Sage Publications, Inc.

[8] Nurgiantoro, B. (2008). Pengembangan Bahan Ajar Bahasa dan Sastra Indonesia. Klaten: MGMP Klaten.

[9] Sungkono. (2003). Pengembangan dan Pemanfaatan Bahan Ajar Modul dalam Proses Pembelajaran. Yogyakarta: FIP UNY.

[10] Undang-Undang Nomor 14 Tahun 2005 tentang Guru dan Dosen, (Online), Retrieved May 13, 2017 from http://kelembagaan.ristekdikti.go.id/undang-undang-nomor-14tahun-2005-tentang-guru-dan-dosen.

[11] Sadiman, A. (2008). Media Pendidikan: Pengertian, Pengembangan, dan Pemanfaatannya. Jakarta: Grafindo Pers.

[12] Arifin, Z. \& Setiyawan, A. (2012). Pengembangan Pembelajaran Aktif dengan ICT. Yogyakarta: Skripta Media Creative.

[13] Sadjati, I.M. (2012). Hakikat Bahan Ajar, (Online), Retrieved May 13, 2018 from http: //repository.ut.ac.id41571IDIK4009-M1.pdf

[14] Ulfah, Anisa. (2017). Pengembangan Media Interaktif untuk Pembelajaran Menulis Cerpen dalam Jurnal IImiah Bahasa dan Sastra. Vol 4 No. 1 June 2017, (Online), Retrieved May 23, 2018 from http://1946-Article\%20Text-3418-1-10-20171121.pdf

[15] Mbulu, J. \& Suhartono. (2004). Pengembangan Bahan Ajar. Malang: Laboratorium Teknologi Pendidikan Fakultas IImu Pendidikan Universitas Negeri Malang.

[16] Muslich, M. (2010). Text Book Writing: Dasar-Dasar Pemahaman, Penulisan, dan Pemakaian Buku Tulisan. Yogyakarta: Ar-Ruz Media. 